\title{
Study on the Right of Silence System in China
}

\author{
Qi Zhang \\ East China University of Political Science and Law \\ Shanghai, China 201620
}

\begin{abstract}
The Criminal Procedure Law of China has stipulated the principle of no forced self-incrimination, which is an implied right of silence. However, the application of the right of silence in China is very controversial. This system is of great value in the investigation and interrogation, but it also faces many challenges. We should build more supporting systems to help guarantee the smooth operation of the right of silence.
\end{abstract}

Keywords-the right of silence system; the right of silence; Miranda Rule; interrogation

\section{INTRODUCTION}

Speaking of the right of silence, one might think of the words of the police in some American detective films: "You have the right to remain silent and refuse to answer questions. Anything you do say may be used against you in a court of law..." This passage is known as the Miranda Warning. However, the right of silence is not so simple, and it has more connotations. The right of silence refers to the right of the respondent (including criminal suspects, defendants) to remain silent and be guided not to testify one's crime when he or she faces the inquisition (including the police, prosecutors, judges). Generally speaking, this right comes from the old saying that "no one is obligated to sue himself" ${ }^{1}$.

For a long time, there has been a controversy in the theoretical circle about whether our country should establish the system of right of silence. When we look into regulation in Chinese Criminal Procedural Law, it says "Nobody shall be forced to incriminate himself". Some of the scholars believes that this rule shows that our country has already established the system of implied right of silence because against forced self-incrimination is one of the basic form of system of right to silence. ${ }^{2}$ The author agrees with this view. However, some scholars insist that the criminal law in China is deeply influenced by the idea of retribution and the interference of the severe punishment doctrine, which leads to the fact that the criminal suspects have no chance to be favored by the right of silence for a long time. 3It can be said

1 Zhao Xiangguo. On the Right of Silence in Criminal Cases [J] Journal of Henan Institute of Education (Philosophy and Social Sciences Edition), 2001(04): 82-83

2 He Jiahong. My Opinion on the Chinese Right of Silence System-Taking American as an example [J]. Political and Law Forum, 2013, 31 (01): 107-114.

Wang Dongsheng. Research on the Procedural Value of the Right of Silence [J].Journal of Liaoning Normal University(Social Sciences Edition),2013,36(03):331-336. that experts have put forward many enlightening insights on the right of silence system in China.

This article will start from the connotation and development process of the right of silence, then analyze its advantages and disadvantages, and explore how to improve this system in China.

\section{THE ORIGIN AND DEVELOPMENT OF THE RIGHT OF SILENCE}

The right of silence was first established in Britain. In 1641, the English parliament overthrew the contempt of court for John Lear sentenced by the Constellation Court, and established a principle that no one should be compelled to answer any questions under the circumstance of putting his or her life or liberty in danger. This principle was later adopted by the United States as the famous "Miranda warning". "You have the right to remain silent and refuse to answer questions. Anything you do say may be used against you in a court of law. "You have the right to consult an attorney before speaking to the police and to have an attorney present during questioning now or in the future. If you cannot afford an attorney, one will be appointed for you before any questioning if you wish. If you decide to answer questions now without an attorney present you will still have the right to stop answering at any time until you talk to an attorney." This is the well-known "Miranda warning" and the beginning of America's right of silence. It stems from a case in which a rapist named "Miranda" appealed to the Supreme Court after police forced him to write down a crime during the interrogation. In the end, the Supreme Court ruled in favour of Miranda, and declared that the police had to inform those arrested of the right of silence. Moreover, if the suspects chose to answer the questions, those words would be used as evidence in the court, otherwise the testimony is invalid. The United States followed the principle of Case Law, and the case became the basis of the "right of silence" in the future. At the same time, the Fifth Amendment of the US Constitution stipulates: "No one shall be compelled to act against himself in any criminal proceedings." The development of the right to silence reached its peak at this time.

\section{RESTRICTIONS ON THE RIGHT OF SILENCE IN VARIOUS COUNTRIES}

Because the Miranda Rule pushes the right of silence to the extreme, judicial practice tends to emphasize due process unilaterally without considering the real situation of the case. 
Many of the cases showed that it is difficult to bring criminals to justice if the right of silence is overused because it had been turned into a safe haven for criminals. The right of silence completely ignores the protection of the victim, making it difficult to get compensation for the loss and trauma suffered by the victim.

During thousands years of legal civilization, the understanding of the role of confession in litigation has undergone several changes. In the middle ages, most of the European countries regarded confession from the suspects as "the king of evidence", and indicated that it was the most important evidence indispensable in the conviction of a crime. No matter what means was adopted, as long as the victim's confession was obtained, the case could be settled. Britain established the right of silence in the 17 th century. The original intention was to weaken the role of confession in conviction, and let the prosecutors bear the burden of proof to prove the crime. But since America established the Miranda Rule in 1966, it has pushed the right of silence to the extreme. According to such a procedure, it seems that in any case, the suspect and the accused do not need to say anything, and the investigation is totally relied on the police to find objective evidence to prove the crime. Unfortunately, not all of these good wishes come true. Judicial practice shows that in many cases, it is impossible to find out the facts of the case if all the parties involved remain silent in the interrogation.

Therefore, Britain has amended its silence right system by setting restrictions of it in many different ways because of the complicated situation in judicial practice. With the continuous progress of the society, Britain has begun to revise its silence right system and limit the use of the right of silence in different ways Since the 1970s. For example, previous laws of Britain did not allow judges and juries to make inferences against an accused in a trial because he remained silent, but later, as long as such inferences were "justified", they were no longer prohibited. This change indicates that the British law implicitly requires the defendant to explain certain behaviors of him when facing charges, which is obviously a restriction on the right of silence of the defendant. At the same time, there have been some changes in the US judiciary in terms of the right of silence also. First, the judge relented when ruling out evidence that the police had violated the Miranda Rule. Some judges in the United States have begun to favor a narrow definition of "witness" in the relevant provisions of the Fifth Amendment to the United States Constitution. In other words, the statement of the accused obtained by the police by illegal means cannot be used, but the subsequent material evidence can be used. In addition, it stipulates that the police do not have to follow the Miranda Rule for activities such as blood drawing and fingerprinting of suspects. The most important exceptions are the exceptions of public safety and emergency. Of course, restrictions on the right of silence do not mean the denial of the right of silence. Up to now, the right of silence is still playing active roles on the stage of western criminal proceedings. The related restriction to the right of silence is actually the gradual perfection of the right of silence, which will make the right of silence play its due effect better.

In the judicial practice of various countries, the right of silence is divided into "implied right of silence "and "express right of silence". The "express right of silence" means that the law clearly stipulates that any law enforcement officer must clearly inform the suspect or defendant of his right to remain silent and don't have to answer questions before being interrogated. Just as the "Miranda Rule" established by the United States in 1966 through a case, if a police officer or a judge fails to perform the duty of informing prior to interrogation, it would be considered illegal to obtain evidence. Even if the confession is obtained, the suspect cannot be found guilty according to this confession. The "Implied right of silence" means that the law does not use the words "you have the right to remain silent" and so on, but acquiesces to the rule that criminal suspects or the defendants do not have to be forced to make selfincrimination. For example, the usual legislative language is that "No one can be forced to prove he is guilt". Some civil law countries, such as Germany and Japan, all adopt this kind of right of silence system. China also adapts this one.

\section{The Benefits of THE Right OF SiLENCE SyStem IN CHINA}

In China's criminal proceedings, the strong investigation power always inevitably encroaches on the citizen's legitimate rights and interests. Therefore, in order to alleviate this situation, it is necessary to strengthen the protection of the criminal suspects' rights in criminal investigation as well as regulate the power of investigation. It requires rational allocation and effective control of the power of investigation. The right of silence is an effective means to restrain the powerful investigation power. The establishment of the silent right system will have a significant impact on our investigation activities.

- The right of silence system helps to reduce the illegal obtaining of testimony by investigators. In China's investigation, the strength of the investigation institution and the criminal suspects is quite unequal, and that is one of the important reasons why the investigators sometimes use violence and other illegal ways to obtain confessions. The investigation institution is backed up by the powerful national power and holds various resources. This makes it difficult for suspects to confront it. Under the realistic background of "confession centrism", the use of violence and other illegal ways to obtain confession occurs frequently. Establishing the right of silence system and giving the accused the right to remain silence can enhance their power of defense to some extent, and balance the power of the investigator and the accused. Although the establishment of the right of silence cannot put an end to the abuse of violence and other illegal ways to obtain confessions, it can also improve this situation to some extent. It helps to prevent the abuse of public power and greatly reduces the occurrence of investigators' illegal actions. 
- It is helpful to improve the criminal suspect's lawsuit subject status. Investigation is the center of the whole criminal procedure, which plays a very important role in finding out the facts of the case. The investigative authorities take a great responsibility of collecting evidence and investigating criminal facts, and practice the investigation power on behalf of the state. Investigation power is a powerful national power, which is often used actively in the process of criminal prosecution and shows strong initiative. In China, the concept of "public interest goes first" is deeply rooted in people's brain. Under the influence of this concept, the priorities of investigation power are often emphasized too much while the rights of citizens, especially criminal suspects and defendants, are often not guaranteed. Therefore, in the field of investigation, the right of investigation is fully used while the right of the suspect is greatly restricted. It results in the serious imbalance of the status of both parties in the process of investigation. The application of the right of silence in the investigation can strengthen the defense of criminal suspects and protect the legitimate rights of criminal suspects to a certain extent.

\section{THE CHALLENGE OF APPLYING THE Right OF SILENCE}

Bentham, a famous English jurist, firmly opposed the right of silence. He left a famous saying that Silence the right of silence is one of the most harmful and the most ridiculous rules that human being can ever find. Then he said in a sarcastic tone as "if each level criminal get together, and according to their wishes to design a system to protect their safety, the right of silence would be there first choice. The innocent will never take advantage of this system. The innocent will assert the right to speak, just as the guilty invoke the right of silence. ${ }^{4}$ There is no perfect system. The reason why the right of silence is so controversial is that its application faces big challenges and will bring many problems.

First, it increases the difficulty of obtaining evidence and reduces the efficiency of investigation. There is an irreconcilable contradiction between the right of silence and the efficiency of investigation. The establishment of the right to silence means that the criminal suspect no longer has the obligation to answer truthfully as stipulated in article 118 of the Criminal Procedure Law. In this way, many suspects may say nothing during the interrogation and be passive during the interrogation. It makes the confession of the suspect reduces. However, the confession of the suspect often contains many important criminal clues. As a matter of fact, investigators can often collect a lot of strong evidence though the criminal suspect's confession. Once the suspect remains silent, investigators will lose some important clues, and then it will become harder to collect other objective evidence. The investigators can only spend more time and

Sun Yongchang(2000). Investigation procedure and human rights, China Fangzheng Press, p. 298 effort to find other evidence to search for clues, through a lot of manpower and material resources and also financial resources find evidence. That would absolutely increase the cost of investigation. Therefore, giving the criminal suspects the right of silence will lead to the long-term backlog of many cases due to the lack of strong evidence, and it will greatly reduce the efficiency of investigation. Many cases show that if the criminal suspect is given the right of silence, it will have negative impacts on the investigation of the cases. Britain, which first established the right of silence, found from years of judicial practice that the right of silence was not conducive to the investigation of the case. The United States has also raised questions about the Miranda Rule, and specified a number of exceptions to the Miranda Rule through legal precedents. The disappearance case of Zhang Yingying, a Chinese student studying abroad in the United States, has been a limelight of the public sight. She has been missing since June 9th, 2017. In this case, the girl has been missing for more than a month, and the suspect has already been arrested. However, facing the court's interrogation, the suspect has remained silent and said nothing about the situation of the girl. Up to now, he still refuses to say a word about Zhang`s whereabouts because he has the right of silence. Therefore, the right of silence has a strong influence on the supreme status of the oral confession. The most direct conflict between the right of silence and the right of interrogation lies in obstructing the collection of testimony. If the right of silence is granted to the criminal suspects during the interrogation of investigation, it implies that the criminal suspect does not have the obligation of "truthful confession", and then the difficulty of obtaining evidence is likely to increase geometrically.

Second, the right of silence leads to the disconnection between the renewal of investigation mode and the actual situation of investigation capability. Faced with criminal suspects who remain silent during interrogation, the investigators have to improve law enforcement intensity, change the investigation strategy and strengthen their investigation ability. The renovation of this investigation mode is undoubtedly a great challenge to the psychological quality of investigators and the cost of investigation technology and economy. However, at the present stage, the investigation system in China is still not efficient enough to provide a solid foundation for handling cases without testimony. It can be seen that the approval of the right of silence may badly affect the efficiency of the interrogation. When the right of investigation and interrogation is limited, the update of the investigation mode will be strongly decoupled from the actual situation of the investigation capability. Eventually, it often leads to the regress of the investigators and the interrogation by torture in a disguised form, which makes the renewal of the investigation mode and the right to silence itself become empty talk.

\section{EstABLISHING THE RIGHT OF SILENCE IN CHINA}

The common law system countries and the civil law system countries have great differences in the pursuit of criminal litigation purposes. The common law system countries pay more attention to the pursuit of procedural 
justice. Therefore, the strength of both sides is matched and both sides are equal. However, the civil law countries pay more attention to the justice of litigation results and focus on the pursuit of substantive justice. In the stage of investigation, the investigation institution is in charge of the investigation, while the criminal suspect is the object of suspicion and investigation, and the investigators may take some measures to prevent the object from hindering the exercise of the investigation power. Under this judicial concept, the right of silence system is difficult to have a place in the civil law system countries. In our country, the purpose of traditional litigation mode of ex officio doctrine is to guarantee the smooth operation of judicial power. As a kind of right to counter the power of state prosecution, the right of silence is hard to be accepted in such a background of litigation system.

The author believes that the right of silence is indeed conducive to the suppression of torture, but the right of silence is by no means a panacea for solving the problem of torture, nor is it the only way to curb torture. Never think that after adoption of the right of silence, the phenomenon of extorting confessions by torture will disappear all of a sudden. It's not that simple. If other problems are not solved, even if the law stipulates the right of silence, there will be a situation of "under the policy, there are countermeasures ". For example, China's current law prohibits the use of torture, and punishes those who use it severely. But some law enforcement officers still carry out violence during the interrogation. From the perspective of legislation, China has given criminal suspects the right of silence in the form of implied silence. From the perspective of judicial practice, the current task is to make this system worthy of the name. The application of the right of silence should be based on the following guarantee mechanism.

- Developing diverse forms of evidence. The right of silence system should not only be established in the law, but also should be comprehensively and objectively understood. In China, oral confession is a traditional form of evidence, and it is the main basis for the investigation institutions to solve cases, which leads to the excessive reliance on oral confession. To some extent, this is also the reason for the prohibition of forced confession by torture, which is not conducive to the implementation of the right of silence. Improving the evidence system, developing diversified forms of evidence and paying equal attention to various forms will help reduce the phenomenon of forced confession by torture, and the case handlers will also pay more attention to the collection of other evidence to help the right of silence system be more effectively guaranteed.

- Improving the presence system of lawyers. In China's current judicial practice, the effective implementation of the right of silence must depend on the perfection of the lawyer system. According to the Criminal Procedure Law of our country, the lawyer has no right to be present when the investigation institution conducts the first interrogation of the criminal suspect. One of the direct consequences of the absence of the lawyer during interrogation is the closed and secret process of the interrogation. The illegal collection of evidence has seriously threatened the legitimacy of the investigation procedure. If a criminal suspect keeps silent, the investigator will probably use violence to obtain confession, and then the right of silence will make no sense. The presence of a lawyer can make the criminal suspect have the possibility of keeping silence. Therefore, the presence system of a lawyer during the interrogation period can help guarantee the right of silence. Criminal suspects and defendants having the right to defense is very essence for human civilization. The right of defense is one of the most important litigation rights. It can be seen that in the case of appropriate restrictions on the right of silence, the channels for defense should be unblocked. Maintaining the proper balance between the prosecution and the defense and ensuring the justice of the lawsuit is the way to seek long-term peace and stability.

- Improving the system of whole-process film recording and voice recording. Now, with the development of social production level, every interrogation room has the economic condition to be equipped with audio and video equipment. The full and comprehensive voice and film recording of the interrogation process can help to guarantee the implementation of the right of silence. When the investigator is accused by the criminal suspect of extorting confessions through torture, the prosecutors and the police can play the audio and video recordings in the court to clearly show the specific interrogations of investigators to prove the legality of the testimony. Where necessary, these videos and recording can be played to the public, and it can greatly enhance the transparency of interrogation, which can effectively reduce and avoid the phenomenon of obtaining evidence by improper means such as torture. This method can help the right of silence to exert its legal effect in a real sense.

- Improving the rules for excluding illegal evidence. The evidence obtained through torture obviously violates the provisions of the right of silence system, so the evidence should be excluded and cannot be used as the basis of the trial. Without relief, there is no right. If the investigators violate the right of silence of the criminal suspect without facing any consequences, such phenomenon will continue. Nowadays, the value of the exclusionary rule of illegal evidence has changed from the original examination of proof ability to the examination of evidence qualification. Therefore, the illegally obtained evidence will not have any legal effect. To some extent, it can effectively curb the motivation of illegal evidence collection of investigators from the source and protect the right of silence of criminal suspects and defendants. 


\section{CONCLUSION}

Criminal proceedings have the dual purpose of punishing crimes and protecting human rights. The measure of a criminal procedure system is whether it can strike a reasonable balance between punishing crime and protecting civil rights. As a means of balancing the power of government, the right of silence is in direct conflict with the right of investigation However, at the same time, it is also a great weapon to protect the civil rights. The right of silence is expected to be used properly. Only by perfecting other supporting systems to escort the exercise of the right of silence, can we establish it with Chinese characteristics.

\section{REFERENCES}

[1] Zhao Xiangguo. On the Right of Silence in Criminal Cases [J]. Journal of Henan Institute of Education (Philosophy and Social Sciences Edition), 2001(04): 82-83.

[2] He Jiahong. My Opinion on the Chinese Right of Silence System Taking American as an example [J]. Political and Law Forum, 2013, 31 (01): 107-114.

[3] Wang Dongsheng. Research on the Procedural Value of the Right of Silence[J]. Journal of Liaoning Normal University(Social Sciences Edition), 2013, 36 (03):3 31-336.

[4] Sun Yongchang. Investigation procedure and human rights, China Fangzheng Press, p. 298.2000. 